\title{
Empowerment of women in situations of social vulnerability
}

O empoderamento das mulheres em vulnerabilidade social

El empoderamiento de las mujeres en vulnerabilidad social

Joanara Rozane da Fontoura Winters*(D); Ivonete Teresinha Schülter Buss Heidemann**(D);

Ana Rosete Camargo Rodrigues Maia***(D); Michelle Kuntz Durand ${ }^{* * * *(D)}$

\section{Abstract}

Background: Empowerment leads to personal freedom, encouraging individuals' participation in collective actions, transforming them, as citizens in their own environment.

Objectives: To identify women's perceptions of their empowerment and autonomy after participation in the Thousand Women Program (Programa Mulheres Mil).

Methodology: Qualitative study based on Paulo Freire's research itinerary. The sample was composed of 9 women participating in the Thousand Women Program.

Results: The problematization methodology used by nursing is a way of increasing women's empowerment. The participants acknowledged their reality and identified topics related to violence against women and the teaching-learning process, reflecting on their perceptions of empowerment, autonomy, and overcoming their situation of vulnerability.

Conclusions: Projects and programs with the purpose of promoting the educational, social, and economic inclusion of women in situations of vulnerability are important for improving these women's professional qualifications and, consequently, their economic autonomy, quality of life, and empowerment.

Keywords: education; learning; personal autonomy; health education

\section{Resumo}

Enquadramento: $\mathrm{O}$ empoderamento conduz à liberdade do indivíduo, fazendo-o participar nas açóes coletivas, transformando-as e exercendo o papel de cidadão no seu ambiente.

Objetivo: Identificar como as mulheres percebem o seu empoderamento e a sua autonomia após a participaçáo no Programa Mulheres Mil.

Metodologia: Pesquisa qualitativa, baseada no itinerário de pesquisa de Paulo Freire. Participaram 9 mulheres inscritas no Programa Mulheres Mil.

Resultados: A metodologia problematizadora utilizada pela enfermagem é um caminho para o desenvolvimento do empoderamento das mulheres. As participantes reconheceram a sua realidade, identificando as temáticas relacionadas com a violência contra a mulher e ao processo ensino-aprendizagem, permitindo a reflexão sobre a sua perspetiva de empoderamento, autonomia e transcendência da sua condição de vulnerabilidade.

Conclusáo: Projetos e programas, criados com o propósito de promover a inclusão educativa, social e económica, como no caso analisado neste estudo, envolvendo mulheres em vulnerabilidade, tornam-se importantes meios para uma melhor qualificação profissional e consequente autonomia económica destas mulheres. Destaca-se também a melhoria na qualidade de vida e a possibilidade de empoderamento das participantes.

Palavras-chave: educação; aprendizagem; autonomia pessoal; educação em saúde

*Ph.D., RN, Federal Institute of Santa Catarina, 89220-618, Santa Catarina, Brazil [joanaraw@ gmail.com]. () http://orcid.org/0000-0002-5564-1521. Contribution to the article: literature se-
arch, experimentation, data collection, data analysis and discussion, article writing. Address for arch, experimentation, data collection, data analysis and discussion, article writing. Address for correspondence: Rua Marcilio Dia, 332 Bairro, América Joinville, 89220-618, Santa Catarina, Brail.
**:Agregaç̃o, Adjunct Professor, Federal University of Santa Catarina, 88040-900, Santa Catarina, **Agregação, Adjunct Professor, Federal University of Santa Catarina, 88040-900, Santa Catarina,
Brazil [ivoneteheideman@gmail.com]. .D http://orcid.org/0000-0001-6216-1633. Contribution Brazil [ivoneteheideman@gmail.com]. O http://orcid.org/0000-0001-6216-1633. Contribution
to the article: literature search, data collection, data analysis and discussion, article writing.
****Agregação, Adjunct Professor, Federal University of Santa Catarina, 88040-900, Santa Catarina, Brazil [ana.maia@ufsc.br]. O http://orcid.org/0000-0002-3353-1225. Contribution to the article: literature search, data collection, data analysis and discussion, article writing.

*****Agregação, Collaborating Professor, Santa Catarina State University, 88035-901, Santa Catarina, Brazil [michakd@hotmail.com]. @ https://orcid.org/0000-0003-3660-6859. Contribution to the article: literature search, data collection, data analysis and discussion, article writing.

\section{Resumen}

Marco contextual: El empoderamiento conduce a la libertad del individuo, le hace participar en las acciones colectivas, transformarlas y ejercer el papel de ciudadano en su ambiente.

Objetivo: Identificar cómo las mujeres perciben su empoderamiento y su autonomía tras la participación en el Programa Mujeres Mil.

Metodología: Investigación cualitativa, basada en el itinerario de investigación de Paulo Freire. Participaron 9 mujeres inscritas en el Programa Mujeres Mil.

Resultados: La metodología problematizadora utilizada por la enfermería supone un camino para el desarrollo del empoderamiento de las mujeres. Las participantes reconocieron su realidad, identificaron las temáticas relacionadas con la violencia contra la mujer, el proceso de enseñanza-aprendizaje, lo que les permitió reflexionar sobre su perspectiva de empoderamiento, su autonomía y la trascendencia de su condición de vulnerabilidad. Conclusión: Proyectos y programas creados con el propósito de promover la inclusión educativa, social y económica, como en el caso analizado en este estudio, que involucra a las mujeres en el tema de la vulnerabilidad, se convierten en importantes medios para una mejor cualificación profesional y la consecuente autonomía económica de estas mujeres. Destaca también la mejora en la calidad de vida y la posibilidad de empoderamiento de las participantes.

Palabras clave: educación; aprendizaje; autonomía personal; educación en salud 


\section{Introduction}

The Thousand Women Program (Programa Mulheres Mil, PMM) was implemented in Brazil, in cooperation with the Canadian Government, from 2007 to 2011. According to the Brazilian Methodological Guide for the Access, Retention, and Success System (Ministério da Educação, 2015, p. 5), the main objective of PMM was to "enable the admission and successful stay of Brazilian socially vulnerable women in vocational schools aimed at their educational inclusion and social and economic promotion". Through training and higher levels of education, the program aimed to provide the conditions necessary for increasing these women's potential for employability and improving their quality of life, as well as the quality of life of their family and community (Portaria n. ${ }^{\circ} 1.015$, de 21 de julho de 2011).

In the transitions theory, Meleis (2012) argues that situational experiences in extremely vulnerable people lead to a psychosocial imbalance which makes it difficult to engage in self-care. Vulnerability has a non-probabilistic nature and contributes to the onset of diseases among individuals who experience a given set of conditions. To achieve a healthy transition process, Meleis (2012) also stresses that nurses need to be familiar with health-promoting strategies, which strengthen the individual and their families and help them to recover their empowerment and autonomy (Meleis, 2012). Therefore, the pedagogical and dialogical activities of the Brazilian program, which was based on the Canadian program, were based on Paulo Freire's ideas. However, the major methodological challenge of PMM was to establish the dialog between the students, create the pedagogical bond between them, and adapt its philosophical approach, taking into account the specificities of the place where the course was taught. Thus, the result was a clear reduction of the social differences among the women involved in the program (Kanaan, 2015).

In 2003, the Federal Government, with former president Luiz Inácio Lula da Silva, created, through Law no. 10.683, of 28 May 2003, the Special Secretariat of Policies for Women (Secretaria Especial de Politicas para Mulheres,
SPM), which aims to promote gender equality and fight against prejudice and discrimination inherited from a patriarchal and excluding society (Câmara dos Deputados, 2003).

The creation of this secretariat and of public policies for women represented a breakthrough in the recognition of women as citizens and strengthened egalitarian achievements and struggles (Kanaan, 2015).

The PMM was designed using a problematization methodology, in which individuals are part of the teaching-learning process. This proposal should be based on learning and reflection and encourage critical thinking, so that individuals can become active subjects capable of changing their reality and becoming more autonomous and, consequently, more empowered (Silveira, Ribeiro, Oliveira, Silva, \& Lima, 2017). In view of the above, this qualitative study, based on Paulo Freire's methodological framework, aims to increase the knowledge about women's empowerment and their transformation within society. The objective of this study was to identify, through problematizing methodologies, women's perceptions of their empowerment and autonomy after participating in the PMM.

\section{Background}

Empowerment can set people free by encouraging participation in community activities and promoting the exercise of citizenship (Tello, 2017).

The term empoderamento is usually the translation for the English word empowerment, which is difficult to interpret when translated into Portuguese and Spanish. It can express dominion, power, conquest, and possession, but also power over someone, which means control, authority. It also means emancipation, that is, becoming free and independent (Souza et al., 2014).

From a critical point of view, empowerment is associated with the transformation and awareness of a society, which leads to liberation. It is the result of a reflective praxis (Freire, 2011).

The methodological approach of PMM, based on concepts of critical pedagogy such as autonomy and problematization of reality encouraged by nursing, promotes the individu- 
als' empowerment to overcome situations of oppression and their health and well-being. "The individual is the agent at the center of the transformation process" (Tello, 2017, p. 101). In this way, the transformation process breaks with the paradigms and "freedom improves the individuals' potential to care for themselves and influence the world, which are key issues in the development process" (Sen, 2010, p. 33).

Empowerment occurs when the individual participates in the development of the other, when he/she is allowed to follow the path of learning, autonomy, and individual and social transformation (Tello, 2017).

Therefore, we decided to use the word empoderamento (empowerment) instead of the descriptor poder (power), which is indexed in the Descriptors in Health Sciences (DeCS).

\section{Research Question}

What are women's perceptions of their empowerment and autonomy after participating in the PMM?

\section{Methodology}

This is a qualitative study based on Paulo Freire's theoretical and methodological framework which comprises the following steps: thematic research, encoding and decoding, and critical unveiling. The study was conducted at the Federal Institute of Santa Catarina (IFSC) with the students enrolled in the PMM.

The PMM was established in the IFSC, Campus Joinville, in 2013, with the purpose of helping socially vulnerable women in the North and Northeast regions of the State who met the program requirements (having a low income or being unemployed and having little or no schooling).

Strategies were used to get women to register in the PMM, which was a requirement of the Secretariat of Vocational and Technological Education (SETEC) and the Ministry of Education and Culture (MEC). For program dissemination, the researchers kept in contact with entities representing the community and used social facilities to recruit women inter- ested in participating in the program.

The sample was composed of nine female students aged 20 to 60 years who were invited to participate in the culture circles through social networks, in the second half of 2016. The invitation was then sent by email. After being explained the purpose of the study, the participants signed the Informed Consent Form. The qualitative research does not determine the number of participants, using small, non-random samples established based on the information needs (Minayo, 2017). In this way, the small number of participants is justified.

The topics were analyzed in Freire's culture circles, which are meetings to discuss social situations. These meetings took place at the IFSC auditorium between September and October 2016, in a total of two circles. They lasted approximately 3 hours. The culture circles promoted the dialog between researchers and participants and encouraged reflection during each intervention.

In the first moment of thematic research, there was a brainstorming: all participants wanted to talk about their experiences in a dynamic session.

This discussion produced nine topics, which were then reduced to five main topics. These topics were encoded, decoded, and unveiled, which allowed participants to perceive a new role of women in society.

The topics were discussed with all women participating in the study, as proposed by Paulo Freire, whose theoretical framework was used to critically address the topics emerging from the culture circles (Durand \& Heidemann, 2013). At this stage, reflection focused on empowerment, women's recognition as citizens, the problematization education, and the teaching-learning methodologies.

At these meetings, the participants' interventions were audio-recorded and transcribed in full after the culture circles, as previously authorized by the participants, who were identified by the letter W followed by an Arabic number.

The research was conducted after approval of the Ethics Committee for Research with $\mathrm{Hu}$ man Beings of the Federal University of Santa Catarina (UFSC) by means of opinion CAA no. 56800516.2.0000.0121, in compliance with the 
requirements of Resolution 466/12 of the $\mathrm{Na}$ tional Committee for Ethics in Research.

\section{Results}

\section{Establishment of the program}

Two courses were established at the Joinville campus of IFSC in the afternoon period: Home Management and Maintenance and Basic Informatics and Social Media. Students could enroll in one of both programs.

Women enrolled in the program had low or no schooling; aged 20 to 60 years; had low-wage jobs or were unemployed (usually house workers); their family structure was in a situation of vulnerability; their educational experiences were negative; and lived in the periphery with difficult access to transport, health, and education. Thus, the "Program promotes these women's human growth by improving their (socio-cultural and economic) living conditions, to the extent that it transforms them into socially and economically empowered citizens" (Ministério da Educação, 2015, p. 4).

\section{Thematic research}

The first culture circle was a relaxed meeting between students and teachers, in which they could talk about themselves. This moment was very productive and affectionate. It was also important because it allowed explaining the objectives of both the study and the meeting and investigate the topics.

In the first circle, all participants talked about their experience with the program and its importance. For women to feel comfortable, after the dialog and conversations, they were given the opportunity to express their feelings through drawings, words or sentences. At this moment, 25 topics were raised. During reflection at this stage, some issues were highlighted related to women's needs which reflect their reality. The following topics were then encoded and decoded: (1) violence against women; (2) women's position in society; (3) teaching-learning process; (4) student-teacher relationship; (5) respect; (6) love; (7) transformation; (8) dialog; (9) family relationships.

\section{Encoding and decoding}

Two of the nine topics were intensely analyzed by the participants in the culture circles: vio- lence against women and teaching-learning process.

The culture circles occurred horizontally and dialogically, respecting the participants. As both topics were being encoded and decoded, the participants reported their experiences of situations involving these topics. The dialog with the participants allowed them to subjectively express immediate problems in their everyday lives.

In this way, the participants began telling their story, until the first topic to emerge was violence against women. At this moment, the reflection focused on the importance of the lecture with the chief of the Women Protection Police Precinct, who explained these types of violence and how to act in case of abuse.

I live with my children, one of them is a drug addict. He offended me, insulted me, swore at me and I was sad and cried. Then I remembered the lecture with the chief, who said that a verbal attack was also a crime, and not only a physical attack. One day, he started to curse me and I had the courage to speak out: If you continue insulting me, I'll have to go to the women's police precinct and file a report because what you're doing is a crime, you're not respecting me as a woman, a mother, a human being, I'm going to call the police. (W1; September 2016)

The dialog on this topic strengthened the connection between the women, who reflected on violence, women's value in society, and empowerment, overcoming their weaknesses. Participants talked about their concerns. Many of them also reported that they were able to impose themselves, as shown in the following extract: "I've been married for 43 years and he was my first boyfriend. We've been together for 46 years and I cook when I want to. I'm not submissive to my husband. He's my partner, my gift from God" (W3; September 2016).

With regard to empowerment, some women talked about overcoming their limitations through the skills acquired in basic informatics courses, notions of ethics, values, and citizenship: "The program taught me how to use a computer, I have a Facebook account, ZapZap. I've participated in other courses; I'm not stopping anymore" (W2; September 2016). 
"I had a German class. I thought: 'What am I going to learn?'. But the teacher taught me things about culture, clothing, history ... things I had never imagined. This is different. I never thought I would learn this" (W1; September 2016).

The issues raised in the culture circles enriched the debate and reflection, which reinforced empowerment.

Another topic discussed in these circles was the teachers' teaching method. Many women had little or no schooling, but all of them said that they had learned a lot during the course due to the way it was taught and the methodologies used, which raised women's interest: "In these lessons, I've learned that I have the courage to fly and follow my dreams" (W4; September 2016).

The classes were group dynamics: "We had to talk about what we had built. I've participated in several courses, but I've learned a lot in this one, it was different" (W6; October 2016).

In this discussion, women also demonstrated that dialog, love, and the teacher-student relationship were essential for a successful teaching-learning process: "The teachers were always cheerful, hugged us, asked if we needed anything. The coordinators were willing to help in an affectionate and supportive way" (W5; October 2016).

This reflection increased women's self-esteem and reinforced their empowerment. Despite the low level of education, women felt safe to study and learn more, and they were encouraged to enroll in other courses to enhance their knowledge, as shown in the following extracts: "It was through the PMM that I completed the course on Warehouse Management, and that motivated me" (W8; October 2016).

"That makeup lesson was much more than teaching us how to do our makeup; it taught us what it means to be a woman. I really felt a Woman. It was very important" (W2; September 2016).

It is clear that during the culture cultures women understood how important they are and how important is their empowerment and their role in society. They also realized that the barrier to teaching and education can only be overcome through dialog and innovative methodologies: "It was after the lecture that I had the courage to file a complaint against my husband. He didn't beat me, but he spied on me all the time." (W9; October 2016).

\section{Critical unveiling}

The critical approach occurred during the action-reflection-action process recommended by Freire. During the culture circles, after the encoding and decoding of the topics of violence against women and teaching-learning process, the women reflected on empowerment, which was strongly unveiled. By discussing the emerging topics, we realized the importance of highlighting and unveiling the topic of empowerment, which was still timidly addressed in the participants' interventions.

At this stage, we performed a retrospective and dialogical reflection on the importance of women's participation in the different areas of daily life. This approach, together with the real social and political empowerment, allowed the participants to become aware and take on a critical position towards the unveiled aspects, which can be clearly seen in the following extract: "It was very difficult for me to learn. I didn't want to take the course. I understood everything because the classes were not taught in the same way as in school. It was different. The teacher taught in a way that I could learn and that made me want to learn more" (W2; September 2016).

\section{Discussion}

In Brazil, the concept of vulnerability has been widely discussed and extended to three different and complementary situations: individual, programmatic, and social. Thus, vulnerability is associated with social inequalities, health inequities, and barriers in the access to health services and practices, leading to family and individual weaknesses due to a violation of rights and insufficient or inexistent support (Chaves \& Ratto, 2018).

In this study, the women participating in the PMM were vulnerable in their everyday spaces, thereby justifying the implementation of the PMM. The proposal to seek new female empowerment strategies goes beyond the program objectives. The change of paradigms and the possibility of new routines, even when the participants have to go to the campus to attend 
classes, were proposed as ways of coping and breaking with the daily routines, leading to greater autonomy and social engagement.

The movement that goes beyond the individual dimension to sharing is a process that starts with the meeting and mutual recognition among individuals, promoting a feeling of belonging to the network and, at the same time, availability to share weaknesses and strengthen women's potential (Albuquerque, Moura, Queiroz, Leite, \& Silva, 2017).

During these meetings, participants shared their experiences, from which emerged the topic of violence against women, experienced mainly in their own homes. This topic should be primarily addressed by nursing through strategies for promoting the involvement of the community, empowerment, social cohesion, and solidarity, as well as reducing social inequalities (Popay et al., 2015).

In the past two decades, it became increasingly more visible that violence against women can contribute to an increased risk of physical and mental health problems. The United Nations (UN) and some governments have considered domestic violence as a legitimate human rights issue (Bozzo, Matos, Beraldi, \& Souza, 2017). In Brazil, according to the Special Secretariat of Policies for Women of the Presidency of the Republic:

Of the total number of cases in the women's contact center in the first half of $2016,12.23 \%$ (67.962) corresponded to reports of violence. Among these reports, $51.06 \%$ corresponded to physical violence; $31.10 \%$, psychological violence; $6.51 \%$, moral violence; $1.93 \%$, patrimonial violence; $4.30 \%$, sexual violence; $4.86 \%$, false imprisonment; and $0.24 \%$, human trafficking. (Câmara dos Deputados, 2003, 2015, p. 5).

Violence has many causes and no association with race, creed, or sociocultural and economic aspects. It refers to power and has the intention of offending, dominating, devaluing women and make them inferior in society. This set of actions make women more vulnerable (Costa, Lopes, \& Soares, 2015).

Therefore, in their relationship with their partners, women who are victims of violence are in a critical situation of insecurity, often of social isolation, unemployed, subjugated by their partners. Women have the right to work, eat, rest, establish relationships, and enjoy their freedom (Albuquerque et al., 2017).

Thus, gender relations are intimately related to power relations. The appropriation of empowerment and, therefore, of power, is different for women and men, which also suggests that the meanings of empowerment and power are also different (Campos, Silva, Miranda, \& Cappelle, 2017).

In this study, we realize that the participants used innovative methodologies as empowerment and reflection tools. Problematization education aims to develop knowledge based on meaningful experiences.

Meaningful learning is established based on the learners' experiences. Students build their own critical-reflective thinking while immersed in different scenarios. This process is essential for students to be able to solve problems (Winters, Prado, Waterkemper, \& Kempfer, 2017).

In the innovative methodology, the mediator facilitates learning and there is a predominance of dialog. The mediator is the agent of transformation who has a liberating role and the learner is the protagonist in the learning process, seeking knowledge. In this way, in this teaching-learning process, human beings are the subject of their own learning, seeking empowerment and autonomy.

Innovative and problematizing methodologies aim to contribute to training citizens in sustainable behavior, health, women's rights, digital inclusion, cooperativism, environmental protection, relationship, and culture. In the PMM, through these methodologies, the "human growth of these women occurs by improving their (socio-cultural and economic) living conditions, to the extent that it transforms them into socially and economically empowered citizens" (Ministério da Educação, 2015, p. 4).

Empowerment does not occur naturally like the biological development processes; it is a construction, a conquest because, as women become more autonomous, they reinforce their power and transform their reality through learning (Kanaan, 2015).

Empowerment can also result from autonomy and intervention in the decision-making process, the transformation of reality, and the improvement of social well-being (Marinho \& 
Gonçalves, 2016).

A limitation of this study was the limited contact with the women because Paulo Freire's research itinerary requires a close relationship between those involved, a bond to enter into a more detailed discussion.

\section{Conclusion}

The use of culture circles based on Paulo Freire's theoretical-philosophical-political thinking gave these women's an opportunity for social inclusion and education; provided a space of hospitality and horizontal dialog without a hierarchy of knowledge and power, which provided them with a feeling of trust, warmth, and self-esteem; promoted a critical reflection about life and raised their awareness about their existence, reshaping their knowledge of their reality.

Through this inclusive approach and reflective learning, the women participating in the culture circles became more capable of leading their own lives and overcoming the limitations and adversities in their family and social life. By becoming more empowered, women were given power and knowledge to cope with the issues oppressing them, such as the different forms of violence (domestic, gender, exclusion by economic condition, and low schooling), and create new opportunities through critical awareness in a permanent reflective process.

This unveiling of reality added value to these women's participation, to the extent that they became more aware of their strength and energy through reflection, sensitive listening, horizontal dialog, and affectionate relationship between facilitator and participants, and the use of innovative technologies of caring for and respecting the other, and by giving them a position of power and hope. The use of innovative care methods and technologies can be considered as a pedagogy of hope, empowerment, and transformation of all forms of oppression and power, a path to the liberation and development of human beings (or female citizens).

As a contribution, we stress the importance of participatory research as a tool for promoting reflection and interventions on women's reality. In this regard, nursing stands out as a potential mediation strategy between vulnerable communities and health care. Nursing, through the dialog in the culture circles and socio-cultural interaction, enabled and strengthened the participants' empowerment.

More opportunities should be created for welcoming vulnerable groups into formal spaces of education and teaching. These spaces should promote the exchange of knowledge and information about women's empowerment, thus promoting their social engagement and liberation from all forms of oppression and exclusion and restoring a sense of hope for these women, their families, and communities.

\section{References}

Albuquerque, N. L., Moura, M. A., Queiroz, A. B., Leite, F. M., \& Silva, G. F. (2017). Isolamento de mulheres em situação de violência pelo parceiro íntimo: Uma condição em redes sociais. Escola Anna Nery Revista de Enfermagem, 21(1), e20170007. doi:10.5935/1414-8145.20170007

Bozzo, A. N., Matos, G. C., Beraldi, L. P., \& Souza, M. D. (2017). Violência doméstica contra a mulher: Caracterização dos casos notificados em um município do interior paulista. Revista Enfermagem UERJ, 25, e11173. doi:10.12957/reuerj.2017.11173

Câmara dos Deputados. (2003). Lei no 10.683 de 28 de Maio. Secretaria de Políticas para as Mulheres, 2015. Brasília, Brasil. Retrieved from http://www2. camara.leg.br/legin/fed/lei/2003/lei-10683-28maio-2003-496772-publicacaooriginal-1-pl.html

Campos, R. C., Silva, K. A., Miranda, A. R., \& Cappelle, M. C. (2017). Gênero e empoderamento: Um estudo sobre mulheres gerentes nas universidades. Revista Latino Americana de Geografia e Gênero, 8(2), 97-115. Retrieved from http://www.revistas2.uepg. br/index.php/rlagg/article/view/9674/pdf6

Chaves, S. E., \& Ratto, C. G. (2018). Fronteiras da formação em saúde: Notas sobre a potência da vulnerabilidade. Comunicação, Saúde, Educação, 22(64), 189-198. doi:10.1590/1807-57622016.0697

Costa, M. C., Lopes, M. J., \& Soares, J. S. (2015). Violência contra mulheres rurais: Gênero e açôes de saúde. Escola Anna Nery Revista de Enfermagem, 19(1), 162-168. doi:10.5935/1414-8145.20150022

Durand, M. K., \& Heidemann, I. T. (2013). Promoção da autonomia da mulher na consulta de enfermagem em saúde da família. Revista Escola Enfermagem USP, 47(2), 288-295. doi:10.1590/S008062342013000200003

Freire, P. (2011). Medo e ousadia: O cotidiano do professor 
(13 a ed.). S. Paulo, Brasil: Saraiva.

Kanaan, H. S. (2015). Quando eu sai de casa: Inventário das politicas públicas e práticas educativas emancipatórias do Programa Mulheres Mil (Master's dissertation). Santa Catarina, Brasil: Universidade da Região de Joinville.

Marinho, P. A., \& Gonçalves, H. S. (2016). Práticas de empoderamento feminino na América Latina. Revista de Estudios Sociales, 56, 80-90. doi:10.7440/ res56.2016.06

Meleis, A. I. (2012). Theoretical nursing: Development and progress (5th ed.). Pennsylvania, PA: Lippincott Williams \& Wilkins.

Minayo, M. C. (2017). Amostragem e saturação em pesquisa qualitativa: Consensos e controvérsias. Revista Pesquisa Qualitativa, 5(7), 1-12. Retrieved from http://rpq.revista.sepq.org.br/index.php/ rpq/article/view/82/59

Ministério da Educação. (2015). Guia metodológico do sistema de acesso, permanência e êxito. Retrieved from http:// portal.mec.gov.br/index.php?option=com_docman\&view=download\&alias=11834-guia-metodologico-setec-pdf\&category_slug=outubro-2012-pdf\&Itemid=30192

Popay, J., Whitehead M., Carr-Hill, R., Dibben, C., Dixon, P., Halliday, E., ... Walterhy, P. (2015). The impact on health inequalities of approaches to community engagement in the New Deal for Communities regeneration initiative: A mixed-methods evaluation. Public Health Research, 3(12), 1-178. doi:10.3310/phr03120
Portaria no 1.015 de 21 de Julho de 2011. Diário Ofcial da União no 140-Secção 1. Ministério da Educação. Brasília, Brasil. Retrieved from http:// portal.mec.gov.br/index.php?option=com_docman \&view $=$ download $\&$ alias $=8589$ - portaria1015-220711-pmm-pdf\&Itemid=30192

Sen, A. (2010). Desenvolvimento como liberdade. São Paulo, Brasil: Companhia das Letras.

Silveira, E. A., Ribeiro, J. E., Oliveira, L. A., Silva N. A., \& Lima E. H. (2017). Uma experiência de educação em saúde entre acadêmicos de enfermagem e adolescentes do projeto PESCAR. Revista de Enfermagem do Centro-Oeste Mineiro, 7, 1931. 1-7. doi: http://dx.doi.org/10.19175/recom.v7i0.1931.

Souza, J. M., Tholl A D., Córdova F. P., Heidemann, I. T., Boehs A. E., \& Nitschke, R. G. (2014). Aplicabilidade prática do empowerment nas estratégias de promoção da saúde. Ciência \& Saúde Coletiva, 19(7), 2265-2276. doi:10.1590/141381232014197.10272013

Tello, R. A. (2017). Tratamento adequado de conflitos: $O$ efetivo acesso à justiça como forma de promoção e empoderamento social no Brasil (Master's dissertation). São Paulo, Brasil: Universidade Nove de Julho.

Winters, J. R., Prado, M. L., Waterkemper, R., \& Kempfer, S. S. (2017). Formação dialógica e participativa na enfermagem: Contribuição ao desenvolvimento do pensamento crítico-reflexivo e criativo de acadêmicos. REME: Revista Mineira de Enfermagem, 21, e1067. doi:10.5935/14152762.20170077 